\title{
Distribution of typical denitrifying functional genes and diversity of the nirS-encoding bacterial community related to environmental characteristics of river sediments
}

\author{
S. Huang ${ }^{1}$, C. Chen ${ }^{1,2}$, X. Yang ${ }^{1}$, Q. Wu ${ }^{1}$, and R. Zhang ${ }^{1}$ \\ ${ }^{1}$ School of Environmental Science and Engineering, Sun Yat-sen University, Guangzhou, Guangdong 510275, China \\ ${ }^{2}$ Department of Natural Resource Sciences, McGill University, Ste-Anne-de-Bellevue, Qecbec H9X 3V9, Canada
}

Received: 7 May 2011 - Published in Biogeosciences Discuss.: 31 May 2011

Revised: 7 October 2011 - Accepted: 17 October 2011 - Published: 31 October 2011

\begin{abstract}
Denitrification in river sediments leads to nitrate removal from the aquatic system; therefore, it is necessary to understand functional diversity of denitrifier communities in the system. Sediment samples $(0-25 \mathrm{~cm}$ depth) were collected from three typical locations along the Pearl River. The real-time PCR approach was used to measure the abundance of nitrate (narG), nitrite (nirS, nirK and nrfA), and nitrous oxide (nosZ) reductase genes from the sediment samples. Assemblages of nirS, nirK and nosZ indicated that complete denitrification occurred in sediment cores, with the greatest number of gene copies from $5-15 \mathrm{~cm}$ depth. Dissimilatory nitrate reduction appeared to be important below $15 \mathrm{~cm}$ depth, based on increasing gene copies of narG and $n r f A$ with sediment depth. There was a close match (78-94\%) between the nirS sequences recovered from the Pearl River sediment and those detected in estuarine and marine sediments as well as active sludge, suggesting that the nitrogen source in the Pearl River sediment was affected by domestic sewage inputs and irregular tides. Canonical correspondence analysis indicated that the spatial distribution of denitrifying bacteria was highly correlated with dissolved inorganic nitrogen (including $\mathrm{NH}_{4}^{+}, \mathrm{NO}_{2}^{-}$and $\mathrm{NO}_{3}^{-}$) concentrations in sediment. It was concluded that the difference in dissolved inorganic nitrogen concentrations along the sediment profile influenced the distribution of denitrifying genes and the nirS-encoding denitrifier community in the river sediment. In addition, a variety of novel denitrifying bacteria were revealed in the river sediment.
\end{abstract}

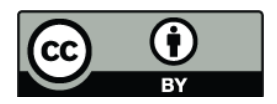

Correspondence to: $\mathrm{Q} . \mathrm{Wu}$ (eeswqh@mail.sysu.edu.cn)

\section{Introduction}

Agricultural and other anthropogenic activities result in increasing amount of nitrogen compounds entering the freshwater and marine systems, causing eutrophication problems. In the microbial process of denitrification, nitrate $\left(\mathrm{NO}_{3}^{-}\right)$ is converted to gaseous forms then lost from the systems (Canfield et al., 2010). Therefore, the denitrification process should help to minimize the eutrophication problems. Since there is a large amount of denitrifiers and nitrogen compounds in eutrophication sediment, sediment is an important environment for nitrogen removal from an aquatic system through denitrification.

Bacterial denitrifiers are taxonomically diverse due to the fact that each bacterial species may participate in only one step of the denitrification process (Burgin and Hamilton, 2007). Denitrification consists of four sequential steps and involves four enzymes. The first step is to reduce $\mathrm{NO}_{3}^{-}$to nitrite $\left(\mathrm{NO}_{2}^{-}\right)$catalyzed by a membrane-bound $\mathrm{NO}_{3}^{-}$reductase (nar) or periplasmic $\mathrm{NO}_{3}^{-}$reductase (nap), which are encoded by the $n a r G$ or the napA genes, respectively. Denitrifying bacteria contain one or both of the $\mathrm{NO}_{3}^{-}$reductase (i.e., narG and napA), in which narG is considered to be more extensive and representative (Deiglmayr et al., 2004; Smith et al., 2007; Reyna et al., 2010). In the second step, $\mathrm{NO}_{2}^{-}$ is reduced to nitric oxide (NO). This reaction distinguishes denitrifier community from other $\mathrm{NO}_{3}^{-}$-reducing bacteria and is catalyzed by two functionally and physiologically equivalent types of $\mathrm{NO}_{2}^{-}$reductases, either a cytochrome cd1 (encoded by nirS) or a Cu-containing enzyme (encoded by nirK) (Glockner et al., 1993). Nir gene sequence diversity in the environment is taken as a measure for diversity of denitrifiers (Priemé et al., 2002; Yan et al., 2003). In the third step, NO is

Published by Copernicus Publications on behalf of the European Geosciences Union. 
reduced to nitrous oxide $\left(\mathrm{N}_{2} \mathrm{O}\right)$, catalyzed by $\mathrm{NO}$ reductase (encoded by the nor $B$ gene). $\mathrm{N}_{2} \mathrm{O}$ is an obligate intermediate, some of which ultimately escapes to the atmosphere. The reduction of $\mathrm{N}_{2} \mathrm{O}$ to nitrogen gas $\left(\mathrm{N}_{2}\right)$ is the last step, which is catalyzed by $\mathrm{N}_{2} \mathrm{O}$ reductase encoded by the nos $Z$ gene present in the periplasm (Throbäck et al., 2004; Chon et al., 2009). These reductase genes are generally used as biological makers of the denitrification process because an approach involving 16S rRNA is not suitable to investigate the diverse community of denitrifying bacteria (Zumft, 1997; Braker et al., 1998).

The distribution of denitrifying genes in sediments are affected by many factors, including concentration gradient of the dissolved inorganic nitrogen (DIN) (including $\mathrm{NO}_{3}^{-}$, $\mathrm{NO}_{2}^{-}$and $\mathrm{NH}_{4}^{+}$), organic matter content, dissolved oxygen, and redox potential (Dong et al., 2009; Reyna et al., 2010). As the depth increases, oxygen concentrations decrease rapidly, microorganism changed from facultative aerobic phylotypes to strictly anaerobic phylotypes, and different denitrifiers (base on nirS diversity) change with the depth (Tiquia et al., 2006). Concentrations of denitrification substrates, among which the DIN and organic matter are most important, also change with the sediment depth (Dalsgaard et al., 2005; Meyer et al., 2008). More gene copies of $\operatorname{nar} G$ and nirS were observed in the river sediment with higher $\mathrm{NO}_{3}^{-}$ concentrations (Chon et al., 2009). Availability of organic matter and carbon/nitrogen ratio determine bacterial biomass and $\mathrm{NO}_{3}^{-}$reduction rates as well as pathways (Burgin and Hamilton, 2007; Dodla et al., 2008). Some dissimilatory $\mathrm{NO}_{3}^{-}$reducing communities compete for $\mathrm{NO}_{2}^{-}$with denitrifying bacteria. These $\mathrm{NO}_{3}^{-}$reducing pathways such as anammox (anaerobic ammonium oxidation) and DNRA (dissimilatory nitrate reduction to ammonium), might appear in different sediment depths according to various carbon/nitrogen ratios (Burgin and Hamilton, 2007). When sediment conditions favor dissimilatory $\mathrm{NO}_{3}^{-}$reducing processes, complete denitrification of $\mathrm{NO}_{3}^{-}$to $\mathrm{N}_{2}$ should be reduced or inhibited. One shortcoming of the previous investigations on this topic is their focus on shallow sediments $(0-10 \mathrm{~cm}$ depth). Competitions among the different denitrification pathways and communities in the sediment profile are still poorly understood. Therefore, further research is needed to study the denitrifying genes and potentially interacting environmental factors in deeper sediments.

The aims of the current study were twofold: (1) to investigate the spatial distributions of denitrifying functional genes (narG, nirS, nirK, nosZ) as well as nrfA, a gene marker for DNRA (Dong et al., 2009) and diversity of denitrifier community along the DIN gradient in the Pearl River sediment, and (2) to determine the relationship between sediment chemistry and denitrifying functional genes in the sediment.

\section{Materials and methods}

\subsection{Sample collection}

The Pearl River is located in the subtropical region in the Guangdong Province, Southern China. This river represents one of the most important ecosystems linking the highly developing land area and the South China Sea. In recent years, the Pearl River has experienced high anthropogenic nitrogen loading due to rapid population increase and economic development.

Sediment samples were collected on 6 April 2010 at three locations along the Pearl River near Guangzhou city, China $\left(23^{\circ} 8^{\prime} \mathrm{N}, 113^{\circ} 17^{\prime} \mathrm{E}\right)$, i.e., from the upstream at Zhujiang Bridge (ZB), midway down the river at Huadi $(\mathrm{H})$, and to the downstream at Ersha (E) (Table 1). The three sample locations were chosen based on the contrasting land use, pollution sources, and aquatic conditions. There is a municipal refuse disposal station near location $\mathrm{ZB}$, resulting in a large amount of polycyclic aromatic hydrocarbons deposited in the sediment. Several small factories are around location $\mathrm{H}$, resulting in chemicals, such as chlorinated compounds and metals, detected in the sediment. Also, a large amount of water lettuces float on the surface at location $\mathrm{H}$, causing a hypoxia condition in the water body. Location $\mathrm{E}$ is close to residential areas, which input sewage to the river. The water depths at the sample locations were about $3 \mathrm{~m}$ and bottom water temperatures were about $23^{\circ} \mathrm{C}$. Salinity was low in this river section, between 1-12\%o depending upon the tide. Dissolve oxygen level was $0.30 \mathrm{mg} \mathrm{L}^{-1}$ in the water-sediment interface and decreased rapidly to $0.01 \mathrm{mg} \mathrm{L}^{-1}$ within $10 \mathrm{~cm}$ sediment (Huang et al., 2011). Three sediment cores were collected at each site within a $2 \mathrm{~m}$ diameter area. Each sediment core was $8 \mathrm{~cm}$ diameter and $30 \mathrm{~cm}$ long. Sediment cores were transported in ice boxes to the laboratory. In the laboratory, each sediment core was sectioned into $5 \mathrm{~cm}$ slices $(0-5,5-10,10-15$, and $20-25 \mathrm{~cm})$ and then put into sterile containers. About half of the sediment sub-samples were used for chemical analysis, which was performed within $24 \mathrm{~h}$ of the sample collection and on 3 replicates per depth. The remaining sediment sub-samples were stored at $-80{ }^{\circ} \mathrm{C}$ for molecular analysis.

\subsection{Analysis of environmental parameters}

Sediment $\mathrm{pH}$ values were determined using a $\mathrm{pH}$ meter (FED20, Mettler, Toledo). Water content and grain sizes of the sediment samples were analyzed using the gravimetric method and pipette method, respectively. By drying a sediment sample overnight at $105^{\circ} \mathrm{C}$ to determine the dry weight, the organic matter content was obtained from the subsequent loss of weight after continuously drying the sample at 550 ${ }^{\circ} \mathrm{C}$ for more than $2 \mathrm{~h}$. Total carbon content (TOC) was calculated based on the organic matter content and the total nitrogen (TN) content was determined using a Foss Kjeltec 2300 
Table 1. Characteristics of sample locations in the Pearl River.

\begin{tabular}{|c|c|c|c|c|c|c|c|c|c|c|c|c|}
\hline \multirow{3}{*}{$\begin{array}{l}\text { Environmental } \\
\text { characteristics }\end{array}$} & \multicolumn{12}{|c|}{ Sample location } \\
\hline & \multicolumn{4}{|c|}{ Zhujiang Bridge (ZB) } & \multicolumn{4}{|c|}{ Huadi $(\mathrm{H})$} & \multicolumn{4}{|c|}{ Ersha $(E)$} \\
\hline & $0-5 \mathrm{~cm}$ & $5-10 \mathrm{~cm}$ & $10-15 \mathrm{~cm}$ & $20-25 \mathrm{~cm}$ & $0-5 \mathrm{~cm}$ & $5-10 \mathrm{~cm}$ & $10-15 \mathrm{~cm}$ & $20-25 \mathrm{~cm}$ & $0-5 \mathrm{~cm}$ & $5-10 \mathrm{~cm}$ & $10-15 \mathrm{~cm}$ & $20-25 \mathrm{~cm}$ \\
\hline Latitude $(\mathrm{N})$ & \multirow{3}{*}{\multicolumn{4}{|c|}{$\begin{array}{c}23^{\circ} 6^{\prime} 50^{\prime \prime} \\
113^{\circ} 17^{\prime} 2^{\prime \prime}\end{array}$}} & \multirow{3}{*}{\multicolumn{4}{|c|}{$\begin{array}{c}23^{\circ} 6^{\prime} 8^{\prime \prime} \\
113^{\circ} 13^{\prime} 22^{\prime \prime}\end{array}$}} & \multirow{2}{*}{\multicolumn{4}{|c|}{$\begin{array}{c}23^{\circ} 7^{\prime} 36^{\prime \prime} \\
113^{\circ} 13^{\prime} 16^{\prime \prime}\end{array}$}} \\
\hline Longitude (E) & & & & & & & & & & & & \\
\hline Sediment & & & & & & & & & & & & \\
\hline Depth layers & ZB5 & ZB10 & ZB15 & ZB25 & H5 & $\mathrm{H} 10$ & H15 & $\mathrm{H} 25$ & E5 & E10 & E15 & E25 \\
\hline $\operatorname{TOC}\left(\mathrm{g} \mathrm{kg}^{-1}\right)$ & 21.9 & 32.1 & 32.3 & 23.9 & 39.7 & 42.5 & 47.9 & 49.8 & 25.7 & 60.9 & 33.6 & 18.9 \\
\hline $\mathrm{NO}_{3}^{-}\left(\mathrm{mg} \mathrm{kg}^{-1}\right)$ & 8.60 & 9.52 & 10.7 & 12.0 & 8.71 & 10.8 & 22.4 & 17.7 & 19.7 & 27.0 & 13.7 & 19.8 \\
\hline $\mathrm{NO}_{2}^{-}\left(\mathrm{mg} \mathrm{kg}^{-1}\right)$ & 0.34 & 0.38 & 0.36 & 0.37 & 0.52 & 0.58 & 0.47 & 0.50 & 1.28 & 0.60 & 0.32 & 0.32 \\
\hline $\mathrm{NH}_{4}^{+}\left(\mathrm{mg} \mathrm{kg}^{-1}\right)$ & 153 & 313 & 818 & 1195 & 194 & 349 & 1273 & 1218 & 1613 & 1867 & 1324 & 1252 \\
\hline
\end{tabular}

Analyzer Unit (Foss Tecator AB, Höganäs, Sweden). Concentrations of $\mathrm{NO}_{3}^{-}, \mathrm{NO}_{2}^{-}$, and $\mathrm{NH}_{4}^{+}$were determined using the methods described by Ryan et al. (2001).

\subsection{DNA extraction}

Three independent samples of nucleic acids for each sediment slice were extracted from $500 \mathrm{mg}$ sediment samples using the Fast DNA spin kit for soil as described in the manufacturer's instructions (Bio 101, Qbiogene Inc., CA, USA). Extraction of DNA was confirmed by gel electrophoresis. The concentration of the extracted DNA was measured using a Nano-drop spectrophotometer (Nano-Drop Technologies, USA) at $260 \mathrm{~nm}$. A test of replicate extractions was performed to ensure reproducible yields from the DNA extractions.

\subsection{Real-time PCR analysis}

Table 2 lists the information on the primers selected for amplification of the different genes encoding 16S rRNA, narG, nirS, nirK, nosZ, and nrfA. Each assay contained a standard curve, independent triplicate sediment DNA templates for each sediment slice, and triplicate no template controls (NTC). Experimental Q-PCR triplicates for each DNA sample were then averaged to obtain a single gene copy number. Real-time PCRs were carried out in LightCycler480 with Sequence Detection Software v1.4 (Applied Biosystems, USA). Each PCR mixture $(10 \mu \mathrm{L})$ was composed of $5 \mu \mathrm{L}$ of SYBR Premix Ex TaqTM II $(2 \times), 0.4 \mu \mathrm{L} 10 \mathrm{nM}$ of

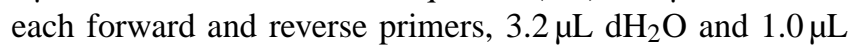
of template DNA (TaKaRa Biotechnology, Japan). PCR amplification and detection were performed in LightCycler480 Multiwell (384-well) reaction plates with optical cap (Applied Biosystems, USA). The PCR temperature program was initiated with $30 \mathrm{~s}$ at $94^{\circ} \mathrm{C}$, followed by 40 cycles of $5 \mathrm{~s}$ at $94^{\circ} \mathrm{C}, 30 \mathrm{~s}$ at the specific annealing temperature (Table 2), and $30 \mathrm{~s}$ at $70^{\circ} \mathrm{C}$. A melting curve analysis for SYBR Green assay was prepared after amplification to distinguish the targeted PCR product from the non-targeted PCR product. The potential presence of PCR inhibitors in sediment DNA extracts was tested by running a real-time PCR assay on serial dilution of sediment DNA extracts. No inhibition was detected in any case. Standard curves for real-time PCR were produced based on a serial dilution of known copies of PCR fragments of the respective functional genes generated using M13 PCR from clones. All the standard curves showed excellent correlations between the DNA template concentration and the crossing point with high coefficients of determination $\left(R^{2}>0.99\right)$. The PCR efficiency was estimated as follows (Bustin et al., 2009)

$E=10^{-1 / S}-1$

where $E$ is the PCR efficiency and $S$ is the slope of the line of standard curve obtained from the tenfold dilution series. The Q-PCR efficiency values for $16 \mathrm{~S}$ rRNA, narG, nirS, nirK, nosZ, and nrfA were $0.964,1.114,0.863,0.987,1.020$, and 1.258 , respectively. The ratios of denitrifying genes to $16 \mathrm{~S}$ rRNA gene extracted from total bacteria were used to evaluate the relative abundances of various denitrifies compared to total bacteria.

\subsection{NirS-encoding bacterial clone library analyses}

The nirS gene fragments ( $\sim 890 \mathrm{bp})$ were amplified using the primer pair nirS1F (5' CCT A(C/T)T GGC CGC C (A/G)C $\left.\mathrm{A}(\mathrm{A} / \mathrm{G}) \mathrm{T} 3^{\prime}\right)$ and nirS6R ( $5^{\prime}$ CGT TGA ACT T(A/G)C CCG T $3^{\prime}$ ) (Braker et al., 1998). PCR amplifications of nirS from environmental samples were performed in a total volume of $50 \mu \mathrm{L}$, containing $5 \mu \mathrm{L}$ of $10 \times \mathrm{PCR}$ buffer $(500 \mathrm{mM} \mathrm{KCl}$, $25 \mathrm{mM} \mathrm{MgCl}_{2}, 200 \mathrm{mM}$ Tris- $\mathrm{HCl}$ [pH 8.4]. $0.1 \%$ Triton X100), $200 \mu \mathrm{M}$ each deoxyribonucleoside triphosohate, $1.0 \mathrm{vU}$ of Taq polymerase $\left(5 \mathrm{U}_{\mu} \mathrm{L}^{-1}\right.$; Appligene Oncor, Illkirch, France), $35 \mathrm{pmol}$ of both primers $\left(5 \mathrm{pmol} \mu \mathrm{L}^{-1}\right.$ each), and DNA (10 ng). After a denaturation step of $5 \mathrm{~min}$ at 95 ${ }^{\circ} \mathrm{C}$, a touchdown PCR was performed (Thermocycler 2400; Perkin-Elmer, Branchburg, N.J.). The touchdown PCR consisted of a denaturation step of $30 \mathrm{~s}$ at $95^{\circ} \mathrm{C}$, a primerannealing step of $40 \mathrm{~s}$, and an extension step of $40 \mathrm{~s}$ at $72^{\circ} \mathrm{C}$. After 30 cycles, a final $7 \mathrm{~min}$ incubation at $72^{\circ} \mathrm{C}$ was 
Table 2. Real time PCR primers used for the amplification of denitrifying genes.

\begin{tabular}{lclcl}
\hline Primer & Target gene & Sequence (5'-3') & Annealing temp & Reference \\
\hline narG328F & narG & GACAAACTTCGCAGCGG & 61 & Reyna et al. (2010) \\
narG497R & $n a r G$ & TCACCCAGGACGCTGTTC & 61 & Reyna et al. (2010) \\
nirS3F & $n i r S$ & CCTA(C/T)TGGCCGCC(A/G)CA(A/G)T & 57 & Braker et al. (1998) \\
nirS5R & $n i r S$ & GCCGCCGTC(A/G)TG(A/C/G)AGGAA & 57 & Braker et al. (1998) \\
NirK1F & $n i r K$ & GG(A/C)ATGGT(G/T)CC(C/G)TGGCA & 57 & Braker et al. (1998) \\
NirK5R & $n i r K$ & GCCTCGATCAG(A/G)TT(A/G)TGG & 57 & Braker et al. (1998) \\
nos1527F & $n o s Z$ & CGCTGTTCHTCGACAGYCA & 57 & Scala and Kerkhof (1998) \\
nos1773R & $n o s Z$ & ATRTCGATCARCTGBTCGTT & 57 & Scala and Kerkhof (1998) \\
nrfA-2F & $n r f A$ & CACGACAGCAAGACTGCCG & 60 & Smith et al. (2007) \\
nrfA-2R & $n r f A$ & CCGGCACTTTCGAGCCC & 60 & Smith et al. (2007) \\
1055f & $16 \mathrm{~S} \mathrm{rRNA}$ & ATGGCTGTCGTCAGCT & 57 & Casamayor et al. (2002) \\
1392r & $16 \mathrm{~S}$ rRNA & ACGGGGCGGTGTGTAC & 57 & Casamayor et al. (2002) \\
\hline
\end{tabular}

performed. During the first 10 cycles, the annealing temperature was decreased by $0.5^{\circ} \mathrm{C}$ every cycle, starting at $45^{\circ} \mathrm{C}$ until it reached a touchdown at $40^{\circ} \mathrm{C}$. The additional $20 \mathrm{cy}-$ cles were performed at an annealing temperature of $43^{\circ} \mathrm{C}$. The amplification products were analyzed by electrophoresis on $1 \%(\mathrm{wt} / \mathrm{vol})$ agarose gels (Genesnap, SYNGENE) followed by a $15 \mathrm{~min}$ stained with Genefinder $\left(0.02 \mu \mathrm{L} \mathrm{mL}^{-1}\right)$. PCR products were purified by agarose gel extraction and cloned into a PMD19-T vector. Positive recombinant clones were identified by colony PCR and the PCR products were cleaned with ExoSap treatment and sequenced on an automated ABI3730 automatic sequencer (Applied Biosystems, USA).

Six sediment sub-samples were selected and used for an extensive analysis of nirS gene diversity as determined through cloning experiments. The six samples were obtained from locations ZB and $\mathrm{H}$ at three depths $(0-5,5-10$, and 10$15 \mathrm{~cm}$ ), respectively. The nirS gene sequences were grouped into operational taxonomic units (OTUs) based on a $5 \%$ sequence distance cutoff calculated using the DOTUR program (Schloss and Handelsman, 2005). Sequences reported in this study were deposited in GenBank database under accession numbers JN016541-JN016591.

\subsection{Phylogenetic analysis}

Datasets of nirS sequences were analyzed using the Bayesian inference (BI) (Huelsenbeck et al., 2001), implemented with MrBayes version 3.1.2 (Ronquist and Huelsenbeck 2003). A best fitting model of nucleotide substitution was identified using the Akaike information criterion (AIC) (Akaike, 1973) as implemented in MrModelTest 2.3 (Nylander, 2004). Bayesian analysis was carried out using GTR $+\mathrm{I}+\mathrm{G}$ model selected by MrModelTest 2.3, in which model parameters were treated as unknown and estimated through the BI. The following settings were applied: implementing two Markov chain Monte Carlo (MCMC) runs, running four simultaneous
Markov chains for 19 million generations, and sampling the Markov chains every 100 generations. Tracer V1.5 (Rambaut and Drummond, 2009) was used to judge convergence of the Bayesian Markov chain Monte Carlo runs. The first 14000 sampled trees were discarded as burn-in. A consensus tree as show in Fig. 1 was constructed from the remaining sampled trees.

\subsection{Statistical analysis}

The coverage of each clone library $(C)$ was calculated by (Mullins et al., 1995)

$C=100 \%[1-(n / N)]$

where $n$ is the number of unique OTUs and $N$ the total number of clones in a library. Indices of gene diversity (ShannonWiener $H$ and Simpson $D$ ) and evenness $(E)$ were calculated using the methods of Schloss and Handelman (2005). Rarefaction analysis and two nonparametric richness estimators, the abundance-based coverage estimator $\left(S_{\mathrm{ACE}}\right)$ and the bias-corrected Chaol ( $S_{\text {Chao1 }}$ ), were calculated using DOTUR (Schloss and Handelman, 2005). Correlations between the gene distributions or nirS-encoding cluster assemblage vs. the environmental factors were analyzed with the canonical correspondence analysis (CCA) (Dang et al., 2008, 2009). In the analysis, the OTU percentage frequency data in each library were used as the species input and the environmental variables were normalized via $\mathrm{Z}$ transformation (Magalhães et al., 2008). Some large deviation of species might appear due to high occurrence of unique sequences. Considered the low coverage, we used the uni-modal CCA analysis to minimize the potential errors. Analyses of Spearman rank, multivariate and stepwise linear regressions of environmental and gene abundance variables were carried out using SPSS v12 on both raw and log-transformed data. All data were analyzed using one way analysis of variance (ANOVA) with the significant level $P<0.05$. 
Table 3. Copy numbers of denitrifying genes and bacterial 16S rRNA genes in the Pearl River sediment.

\begin{tabular}{lcccccc}
\hline & & \multicolumn{5}{c}{ Ratios } \\
\cline { 3 - 7 } Layer & \begin{tabular}{c} 
16S rRNA gene \\
\cline { 3 - 7 }
\end{tabular} & $\begin{array}{c}\text { narG/16SrRNA } \\
\left(\times 10^{-3}\right)\end{array}$ & $\begin{array}{c}\text { nirS/16SrRNA } \\
\left(\times 10^{-2}\right)\end{array}$ & $\begin{array}{c}\text { nirK/16SrRNA } \\
\left(\times 10^{-3}\right)\end{array}$ & $\begin{array}{c}\text { nosZ/16SrRNA } \\
\left(\times 10^{-3}\right)\end{array}$ & $\begin{array}{c}\text { nrfA/16SrRNA } \\
\left(\times 10^{-3}\right)\end{array}$ \\
\hline ZB5 & $4.91 \pm 0.18^{\mathrm{a}}$ & $7.24 \pm 0.12$ & $13.1 \pm 1.24$ & $6.37 \pm 1.22$ & $7.24 \pm 2.22$ & $17.5 \pm 4.11$ \\
ZB10 & $1.58 \pm 0.42$ & $9.69 \pm 0.23$ & $11.3 \pm 1.03$ & $3.22 \pm 0.32$ & $11.6 \pm 5.67$ & $21.7 \pm 5.17$ \\
ZB15 & $1.75 \pm 0.66$ & $6.65 \pm 0.11$ & $3.30 \pm 0.17$ & $2.10 \pm 0.09$ & $9.68 \pm 4.32$ & $23.6 \pm 3.39$ \\
ZB25 & $0.31 \pm 0.14$ & $3.52 \pm 0.08$ & $4.88 \pm 0.19$ & $2.05 \pm 0.17$ & $2.10 \pm 0.15$ & $25.9 \pm 5.26$ \\
H5 & $1.26 \pm 0.33$ & $3.06 \pm 0.10$ & $26.8 \pm 3.28$ & $7.35 \pm 1.03$ & $4.94 \pm 0.23$ & $32.4 \pm 3.57$ \\
H10 & $0.98 \pm 0.64$ & $10.9 \pm 0.38$ & $20.7 \pm 2.17$ & $4.21 \pm 0.54$ & $6.63 \pm 0.28$ & $29.9 \pm 2.48$ \\
H15 & $0.57 \pm 0.14$ & $12.2 \pm 0.42$ & $6.70 \pm 0.28$ & $2.87 \pm 0.12$ & $2.73 \pm 0.08$ & $37.1 \pm 2.16$ \\
H25 & $0.20 \pm 0.05$ & $13.7 \pm 0.33$ & $4.38 \pm 0.12$ & $2.33 \pm 0.13$ & $6.31 \pm 0.48$ & $33.9 \pm 3.11$ \\
E5 & $3.37 \pm 0.29$ & $1.37 \pm 0.03$ & $2.94 \pm 0.11$ & $5.21 \pm 0.23$ & $0.34 \pm 0.05$ & $7.98 \pm 1.21$ \\
E10 & $2.40 \pm 0.09$ & $2.48 \pm 0.12$ & $9.45 \pm 0.80$ & $2.45 \pm 0.09$ & $1.93 \pm 0.08$ & $9.29 \pm 2.47$ \\
E15 & $1.39 \pm 0.07$ & $2.43 \pm 0.14$ & $5.60 \pm 0.58$ & $2.01 \pm 0.11$ & $1.48 \pm 0.27$ & $10.6 \pm 1.18$ \\
E25 & $1.63 \pm 0.32$ & $4.88 \pm 0.16$ & $6.55 \pm 0.71$ & $1.87 \pm 0.07$ & $1.09 \pm 0.09$ & $33.5 \pm 5.02$ \\
\hline
\end{tabular}

a The values represent the mean and standard error $(n=3)$.

\section{Results}

\subsection{Environment conditions of Pearl River sediments}

The sediments were mainly soft silt, and had a light hydrogen sulfide smell. As shown in Table 1, on average, DIN contents were rather high, especially $\mathrm{NH}_{4}^{+}$, compared to other river sediments (Richardson et al., 2004; Laverman et al., 2010). DIN concentrations of the sediment surfaces $(0-5 \mathrm{~cm})$ increased from locations $\mathrm{ZB}$ to $\mathrm{E}$, such that $\mathrm{NO}_{3}^{-}, \mathrm{NO}_{2}^{-}$, and $\mathrm{NH}_{4}^{+}$increased from $8.60,0.34$, and $153 \mathrm{mg} \mathrm{kg}^{-1}$ to 19.7 , 1.28 , and $1613 \mathrm{mg} \mathrm{kg}^{-1}$, respectively. DIN concentrations at location $\mathrm{E}$ were much higher than those at the other sampling locations, which were attributable to the inputs of domestic wastewater. Tides might be another factor to cause the pollutant accumulation. $\mathrm{NO}_{3}^{-}$and $\mathrm{NH}_{4}^{+}$increased with the sediment depth at locations $\mathrm{ZB}$ and $\mathrm{H}$. Nitrate concentrations at locations $\mathrm{ZB}$ and $\mathrm{H}$, respectively, changed from 8.60 and $8.71 \mathrm{mg} \mathrm{kg}^{-1}$ in the sediment surface to 12.0 and $17.7 \mathrm{mg} \mathrm{kg}^{-1}$ in the bottom layer, while $\mathrm{NH}_{4}^{+}$concentrations changed from 153 and $194 \mathrm{mg} \mathrm{kg}^{-1}$ to 1195 and 1218 $\mathrm{mg} \mathrm{kg}{ }^{-1}$, respectively. Nitrate and $\mathrm{NH}_{4}^{+}$concentrations at location $\mathrm{E}$ were the highest among sample locations, while $\mathrm{NO}_{3}^{-}$and $\mathrm{NH}_{4}^{+}$concentrations at location $\mathrm{E}$ showed insignificant variations with the sediment depth. In contrast, the vertical change of $\mathrm{NO}_{2}^{-}$at location $\mathrm{E}$ was significant, and the concentrations were highest at the sediment surface and decreased with depth of $0-15 \mathrm{~cm}$. TOC was abundant in the sediment and the maximum content appeared in E10 $(10 \mathrm{~cm}$ depth at location E) layer $\left(60.9 \mathrm{~g} \mathrm{~kg}^{-1}\right.$, Table 1$)$. TOC values increased gradually from locations ZB to E.

\subsection{Relative abundances of different denitrifying genes}

Distributions of the denitrifying genes (narG, nirS, nirK, $n o s Z$, and $n r f A$ ) varied between the three sampling locations. Although the highest concentrations of DIN and TOC appeared at location $\mathrm{E}$, the relative abundance of denitrifying genes was the lowest at this location. The lowest abundance of $16 \mathrm{~S}$ rRNA was founded at location $\mathrm{H}$, whereas the relative abundance of denitrifying genes was the highest at this location (Table 3 ). The relative contributions of nirS gene to total bacteria were the highest among the denitrification genes at all locations. Abundances of $16 \mathrm{~S}$ rRNA decreased with the sediment depth at the three sampling locations.

The relative abundance of narG gradually increased with the sediment depth except for location $\mathrm{ZB}$ with the lowest proportion at $25 \mathrm{~cm}$ depth. For nirS and nirK, the relative abundance was high within the depth of $0-10 \mathrm{~cm}$ and decreased rapidly below $10 \mathrm{~cm}$. Since the proportion of nir genes can represent the potential denitrification rate (Dong et al., 2009; Graham et al., 2010), the result indicated that nitrite reduction process should mainly occur above $10 \mathrm{~cm}$ in the sediment. For nos $Z$, the highest proportions appeared in the depth of $5-15 \mathrm{~cm}$. Interestingly, different from other denitrifying genes, relative abundance of nos $Z$ was higher at location ZB. For $n r f A$, the relative abundance also gradually increased with sediment depth except for location $H$. It was noted that the total $n r f A$ numbers actually decreased with the depth although the relative abundance of $n r f A$ increased with the depth. 
Table 4. Biodiversity and predicted richness of nirS sequences recovered from six layers in the Pearl River sediment.

\begin{tabular}{lcccccc}
\hline Layer & Coverage $(\%)$ & Shannon $(H)$ & Simpson(1/D) & Evenness $(E)$ & $S_{\text {ACE }}$ & $S_{\text {Chao1 }}$ \\
\hline ZB5 & 85.5 & 2.82 & 7.72 & 0.83 & 66.0 & 64.3 \\
ZB10 & 78.5 & 3.07 & 8.16 & 0.82 & 97.9 & 119 \\
ZB15 & 72.4 & 3.43 & 9.13 & 0.78 & 129 & 130 \\
H5 & 74.8 & 3.25 & 8.91 & 0.75 & 109 & 168 \\
H10 & 70.8 & 4.15 & 13.6 & 0.86 & 146 & 142 \\
H15 & 65.3 & 4.39 & 15.6 & 0.84 & 135 & 107 \\
\hline
\end{tabular}

\subsection{Phylogenetic diversity of nirS-encoding bacteria}

The nirS gene libraries from the layers of ZB5, ZB10, ZB15, $\mathrm{H} 5, \mathrm{H} 10$, and $\mathrm{H} 15$ resulted in totally 305 nirS gene sequences from clones. These nirS gene sequences were assigned to 51 OTUs based on a $5 \%$ cutoff. The coverage of these nirS clone libraries was $86 \%, 79 \%, 72 \%, 75 \%, 71 \%$, and $65 \%$ in the layers ZB5, ZB10, ZB15, H5, H10, and H15, respectively. The diversity indexes of these libraries suggested a slightly increasing diversity of the denitrifying bacterial community with increasing depth (Table 4). The rarefaction curve suggested a similar trend (data not shown).

Nitrite reductase gene sequences from the Pearl River sediment were similar to those of other typical estuarine and marine environments, as well as sewage treatment systems. A phylogenetic tree indicated that the 51 nirS OTUs could be classified into nine clusters (Cluster-A to Cluster-I) base on their class and function (Fig. 1). Cluster-A dominated in all clone libraries with $57 \%, 80 \%, 52 \%, 63 \%, 61 \%$, and $65 \%$ in the layers of ZB5, ZB10, ZB15, H5, H10, and H15, respectively. This cluster belonged to the family Rhodocyclaceaewhich contained mainly aerobic and denitrifying rodshaped bacteria with very versatile metabolic capabilities (Martins et al., 2010; Wongwilaiwalin et al., 2010). One OTU was closely related to the family Comamonadaceae. Both these families were usually found in aquatic sediment habitats, constructed wetland, and activated sludge (RuizRueda et al., 2007; Spain et al., 2007). Sequences of ClusterB were similar to species Ralstonia eutropha strain (78-90\% indentify), belonging to the family Burkholderiaceae. R. eutropha H16 was previously known as Alcaligenes eutrophus and originally isolated from sludge. Cluster-C was closely affiliated with the species Thiobacillus denitrificans. This is a chemoautotrophic bacterium using sulfide as electron donor (Beller et al., 2006). The bacterium was only detected in deeper layers at location $\mathrm{ZB}$ with $3.3 \%$ and $8.7 \%$ in ZB10 and ZB15. Cluster-D had high sequence similarity (88-94\% identity) with an environmental clone from Chesapeake Bay sediment (Bulow et al., 2008), accounting for $7.1 \%, 6.7 \%, 13.0 \%, 6.3 \%, 13.0 \%$, and $20.0 \%$ in layers of ZB5, ZB10, ZB15, H5, H10, and H15, respectively. Cluster$\mathrm{E}$ was detected in the sediment of location $\mathrm{H}$ with $12.5 \%$,
$17.4 \%$, and $10 \%$ of the total number of clones in $\mathrm{H} 5, \mathrm{H} 10$, and $\mathrm{H} 15$, respectively. Clones in this cluster were related to species Dechloromonas aromatic. Cluster-F was related to species Aromatoleum aromaticum (80-92\% identity) and mainly appeared in ZB sediment with the largest percentage (40\%) for layer ZB10. Cluster-G and Cluster-H were only detected in deeper layer at location $\mathrm{H}$, accounting for $4.3 \%$ and $4.4 \%$ in layer $\mathrm{H} 10,10.0 \%$ and $5.0 \%$ in layer $\mathrm{H} 15$, respectively. Sequences of Cluster-G were related to Magnetospirillum sp. (84\% identity), which was a Gram-negative $\alpha$-proteobacterium. This is a group of facultative anaerobic bacteria related to iron oxidation (Matsunaga et al., 2005). Cluster-H was related with Herbaspirillum sp. and belonged to the family Burkholderiaceae. These bacteria were usually found in the rhizosphere of soil and sediment environments. They were considered to participate in nitrogen fixation (Jung et al., 2007). Cluster-I belonged to the family Candidatus Accumulibacter, which was ecologically significant because it was used to remove phosphorous from waste water (Fukushima et al., 2007). Cluster-I appeared in ZB5, ZB10, ZB15, H5, and H10, accounting for $14.3 \%, 13.3 \%$, $4.4 \%, 12.5 \%$, and $8.7 \%$, respectively.

\subsection{Spatial distributions of denitrifying genes and the nirS-encoding bacterial assemblage}

Spatial distributions of denitrifying genes and nirS-encoding bacterial assemblages might be influenced by nutrient conditions in the Pearl River sediment. The CCA analysis of denitrifying gene abundance and nirS-encoding bacterial assemblages in response to environmental variables confirmed the influence. In Fig. 2a, the first two CCA axes (CCA1 and CCA2) explained $73 \%$ of the total variance in the denitrifying gene abundance and $83 \%$ of the cumulative variance of the gene-environment relationship. Dissolved inorganic nitrogen had significant effects on distributions of denitrifying genes. The CCA analysis showed that CCA1 represented the vertical distributions of denitrifying genes. Nitrite reductase genes mainly assembled in $0-10 \mathrm{~cm}$ in the sediment and $n o s Z$ distributed in $5-15 \mathrm{~cm}$, while a large number of narG and $n r f A$ genes gathered below $15 \mathrm{~cm}$. Distributions of denitrifying genes had obvious stratification in the Pearl River 


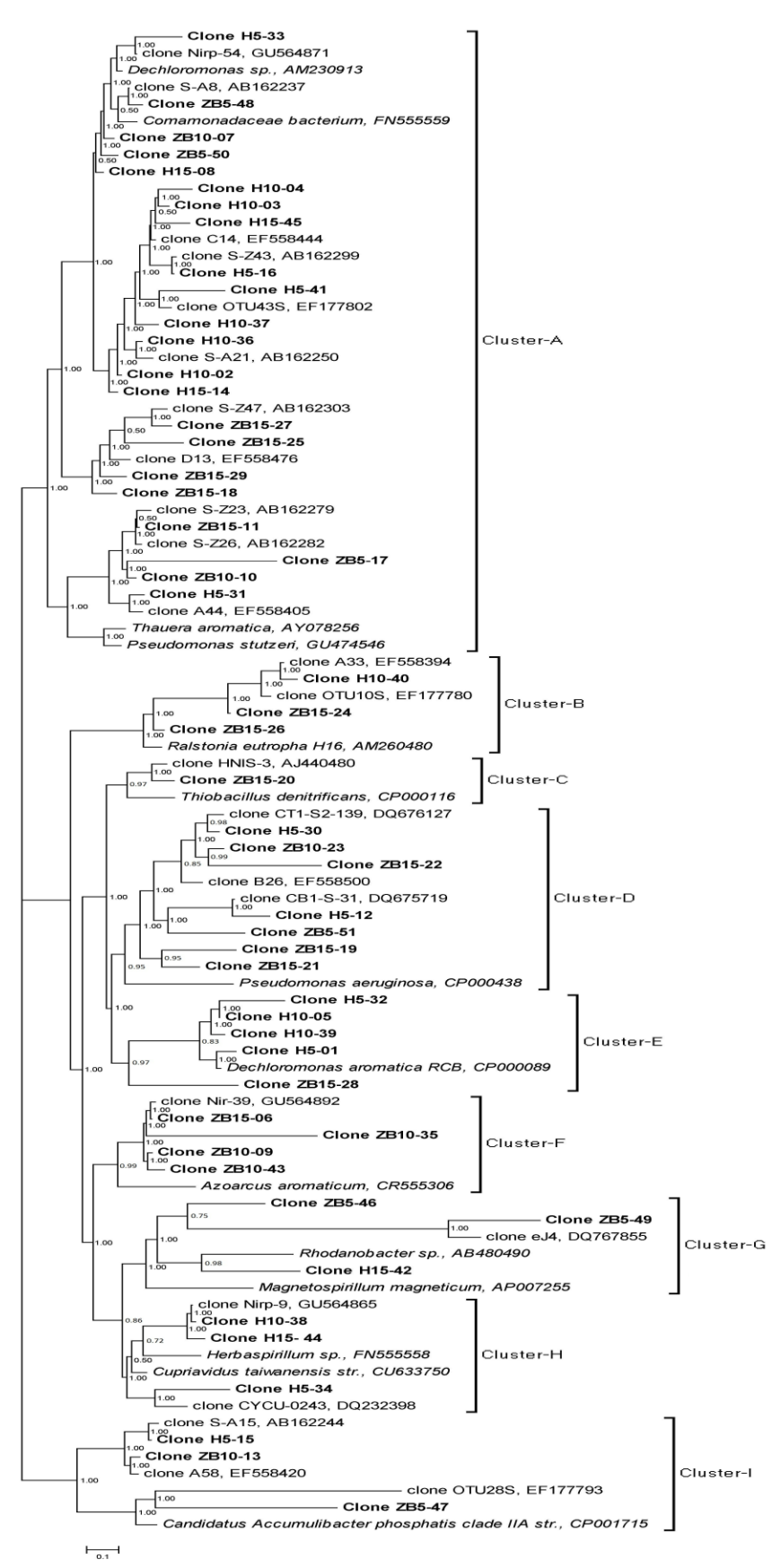

Fig. 1. Phylogenetic tree of PCR-amplified nirS gene. The tree was constructed using the Bayesian inference (BI) methods with nirS sequences from the Pearl River sediment and from other typical estuarine and marine environments, as well as sewage treatment systems. Sequences determined in this study are in bold. Bootstrap values were based on 1000 replicates each and are shown at the nodes with $>50 \%$ bootstrap support. OTUs with bootstrap value either $>80 \%$ were utilized to designate the nirS phylogenetic clusters. The scale bar represents $10 \%$ sequence divergence. sediment (Fig. 2a). CCA2 represented the nutritional level of the sediment. Results show that TOC was not limited to the distribution of denitrifying genes (Fig. 2a). Concentrations of $\mathrm{NH}_{4}^{+}$were significantly affecting $n r f A$ distributions $(P=0.025)$, and $n i r S$ and nirK abundance was correlated with $\mathrm{NO}_{2}^{-}(P=0.032)$. Distributions of nar $G$ were affected by the combined effects of DIN. However, nos $Z$ was negatively related to various sediment nutritional factors, which indicated that oligotrophic conditions might promote the activity of nosZ (Fig. 2a).

In Fig. 2b, the first two CCA axes (CCA1 and CCA2) explained $71 \%$ of the total variance in the nirS-encoding bacterium composition and $81 \%$ of the cumulative variance of the bacteria-environment relationship. CCA1 and CCA2 distinguished the nirS-encoding bacterial assemblage of layer ZB15 from those of the other layers. TOC and $\mathrm{NO}_{2}^{-}$contributed more to the bacteria-environment relationship than the other environmental factors (Fig. 2b). The distribution of Cluster-D was positively correlated with $\mathrm{NH}_{4}^{+}$and Cluster-E was related to TOC and $\mathrm{NO}_{3}^{-}$. However, the distributions of Cluster-F and Cluster-I were negatively correlated with the nutrient-rich conditions. Along the most important CCA1 axis, Cluster-D, -E, -G, and Cluster-H might correspond to the nutrient-rich conditions in the sediment, whereas Cluster$\mathrm{F}$ and Cluster-I corresponded to the less eutrophic conditions (Fig. 2b). Various denitrifier communities were found among the different locations and sediment depths.

\section{Discussion}

The spatial distributions and concentrations of DIN in the sediment clearly showed the urban river characteristics of the Pearl River. Because of a large amount of domestic wastewater inputs, various pollution characteristics appeared at different locations. Concentrations of $\mathrm{NH}_{4}^{+}$in the sediment of this river section were higher than those of other rivers, and the vertical variations of $\mathrm{NO}_{3}^{-}$, which accumulated at deeper layers, were different from those in other river sediments (Tiquia et al., 2006; Laverman et al., 2010). Previous studies showed that denitrifying bacterial diversity was higher at deeper sediment layers, but denitrification rates of deeper sediments could be neglected due to the absence of oxidized $\mathrm{NO}_{3}^{-}$and $\mathrm{NO}_{2}^{-}$(Tiquia et al., 2006). However, $\mathrm{NO}_{3}^{-}$concentrations did not decrease with the sediment depth in the Pearl River and the relative abundance of narG was higher at deeper sediment layers (Tables 1 and 3). These results indicated that $\mathrm{NO}_{3}^{-}$reduction rates in the deeper sediments could not be neglected in the river region. Dramatically decrease of abundances of nirS and nirK below $15 \mathrm{~cm}$ did not cause $\mathrm{NO}_{2}^{-}$accumulation, indicating that there were other $\mathrm{NO}_{2}^{-}$reduction pathways in the deeper sediment. Relative abundance of $n r f A$ increased with the sediment depth and DNRA might become more active in the deeper sediment. However, low $\mathrm{C} / \mathrm{N}$ below $15 \mathrm{~cm}$ inhibited the DNRA process (Burgin 
O Sample locations $\Delta$ Denitrifying genes (a) or nirs clusters (b) $\rightarrow$ Environmental factors.
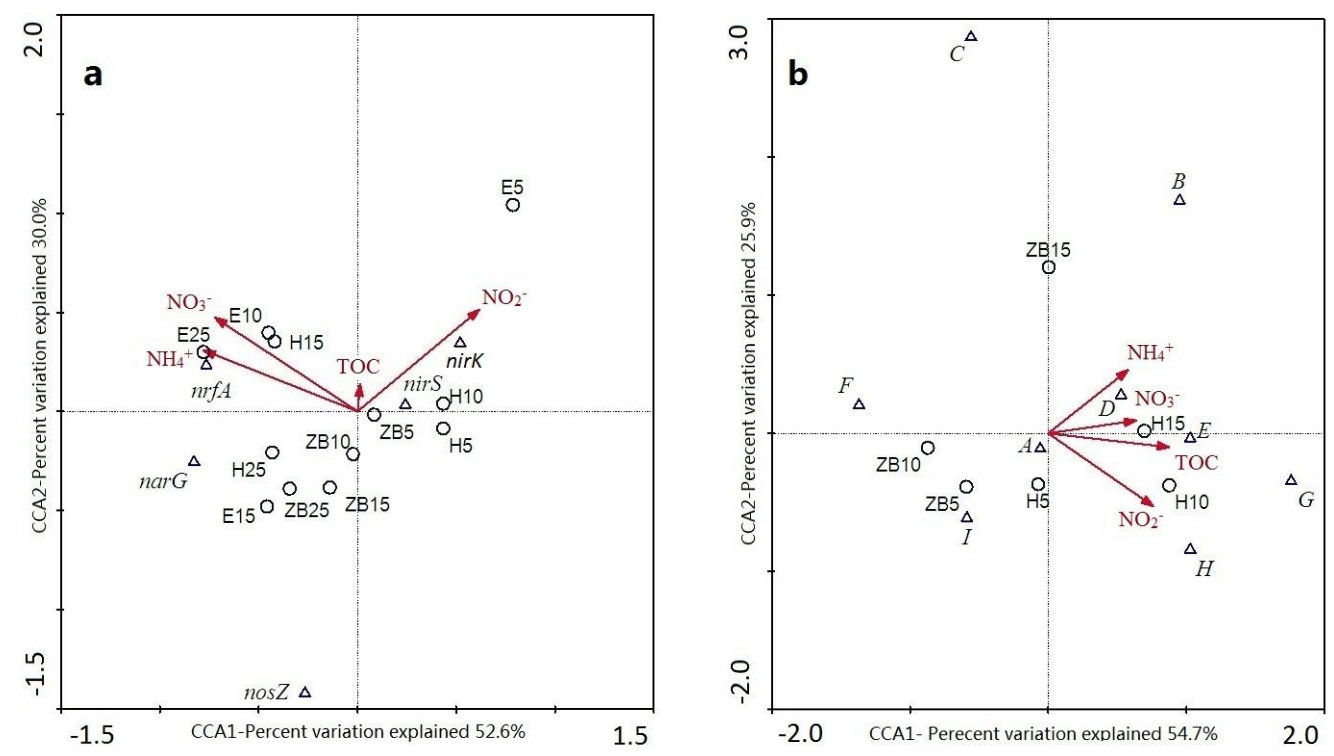

Fig. 2. Ordination plots of the canonical correspondence analysis (CCA) for the first two dimensions of CCA of the relationship between the distributions of (a) denitrifying genes and (b) nirS clusters vs. the nutrients in the Pearl River sediment. Correlations between environmental variables and CCA axes are represented by the length and angle of arrows (environmental factor vectors).

and Hamilton, 2007). Therefore other metabolism pathways, such as anammox that drives $\mathrm{N}_{2}$ production in the marine and estuarine environments, might be important processes to consume $\mathrm{NO}_{2}^{-}$in this river sediment (Kuypers et al., 2003; Dalsgaard et al., 2005). The $\mathrm{N}_{2}$ generate efficiency of anammox and its impact on denitrification needs further studies. Our results showed that denitrification processes in different sediment depths were dominated by different $\mathrm{NO}_{3}^{-}$and $\mathrm{NO}_{2}^{-}$ reduction pathways. Therefore, it is essential to study the vertical distribution of denitrification in the river sediment.

In this study, both nirK and nirS were detected in the Pearl River sediment. However, nirK abundance was much lower than nirS abundance in the sediment because nirK only prevails in conditionally oxygen-exposed environment (Desnues et al., 2007; Knapp et al., 2009). The enzymes encoded by nirS and nirK require different substrates. Particularly environmental conditions may alter the proportion of denitrifiers with nirK or nirS. Moderate levels of $\mathrm{NO}_{3}^{-}$in the river sediment increase nirS diversity (Yan et al., 2003). The nirS gene is found to be more widespread in the bacterial communities in various sediments (Priemé et al., 2002; Liu et al., 2003; Throbäck et al., 2004; Tiquia et al., 2006; Oakley et al., 2007; Dang et al., 2009). Therefore, we used the nirS gene to characterize the diversity of denitrifier communities in the Pearl River sediment. Most of the nirS sequences in this sediment had a close match with those originally detected in estuarine and marine sediments as well as sludge (Nogales et al., 2002; Tsuneda et al., 2005; Osaka et al., 2006; Ruiz-Rueda et al., 2007; Spain et al., 2007; Bulow et al., 2008), suggesting that this river has both tidal and urban characteristics. When the river is affected by both domestic pollutions and irregularly tides, diversity and distributions of denitrifying bacteria should become more complicated. In comparable environments, similar denitrifying communities may develop despite of different geographical locations (Castro-Gonázlez et al., 2005; Falk et al., 2007). Sediments from locations ZB and $\mathrm{H}$ were use to study the diversity of denitrifier community according to the high abundance of $n i r S$ genes in these locations. Some of the nirS gene sequences were unique with the sampling locations, and several nirS gene sequences were novel in the Pearl River, as most of them had $<70 \%$ nucleic acid identity with those from cultivated strains and $<90 \%$ identity with those from environmental clones. Cluster-G and Cluster-H were only detected at location $\mathrm{H}$, corresponding to the serious pollution created by the aquatic plants and metal release at this location. Bacteria of Cluster-E and Cluster-F, which utilize different aromatic compounds, appeared only in the sediments of locations $\mathrm{H}$ and $\mathrm{ZB}$, respectively, due to different categories of polycyclic aromatic hydrocarbons (Chakraborty et al., 2005; Tamang et al., 2009). It was very likely that at least some of these bacteria were the contaminant-degrading species in the nirS communities. Existence of many novel bacteria was another reason for the lower abundance of $\operatorname{nar} G$ compared to nirS in this environment (Table 1). Further research is needed to cultivate the novel denitrifying bacteria, to study their ecophysiology, and to understand their roles and mechanisms in $\mathrm{N}$ cycling and environmental bioremediation. In addition, more specific primers should been designed and verified experimentally. 
In this study, besides the abundance of denitrifying genes, the composition of denitrifying bacterial communities based on nirS gene also showed vertical variations. Denitrifier communities were dominated by a few phylotypes in the surface layers and showed higher diversity in the deeper layers. On the other hand, unique denitrifying bacterial phylotypes appeared in the different sediment depths (Table 4 and Fig. 1). Denitrifying bacteria changed from facultative aerobic phylotypes to strictly anaerobic phylotypes attributable to the decrease of dissolved oxygen with the sediment depth. Bacteria of Cluster-I was facultative denitrifying bacteria, which preferred low dissolved oxygen conditions and usually accumulated in the upper sediments (Fukushima et al., 2007). Nitrification and denitrification processes can simultaneously occur in the surface sediment, thereby increasing the reduction rates of $\mathrm{NO}_{3}^{-}$and $\mathrm{NO}_{2}^{-}$(Rysgaard et al., 1993; Scott et al., 2008). R. eutropha H16 of Cluster-B, which preferred non-halophilic habitats and did not require oxygen, appeared in the deeper sediment (Schwartz et al., 2003). With the capability to carry out DNRA processes, bacteria of Cluster-D did not exist in the sediment surface, but the bacterial proportion became remarkable with the sediment depth. All of these results suggested that the vertical distributions of denitrifying genes in this sediment had a similar stratified characteristic, and that transformation, competition, and cooperation of different denitrifier communities were determined by the depth-dependent sediment characteristics. Based on the stratified characteristic, the sediments could be divided generally into three layers. In our sediment, at $0-5 \mathrm{~cm}$, synchronic nitrification and denitrification processes dominated in this low oxygen environment (Fan et al., 2006). At 5$15 \mathrm{~cm}$, nitrite reductase gene (nirS and nirK) and nosZ were concentrated, potential denitrification ability was high, and the complete denitrification process (with the final product of $\mathrm{N}_{2}$ ) accommodated this environment (Graham et al., 2010). Below $15 \mathrm{~cm}$, a strictly anoxic condition limited nitrification, thus a large amount of $\mathrm{NH}_{4}^{+}$accumulated and dissimilatory $\mathrm{NO}_{3}^{-}$reducing pathways became obvious. Although the exact depth range of each layer may vary for different sampling locations, the stratification pattern of denitrification should be prevalent in different sediments (Fan et al., 2006; Tiquia et al., 2006).

Among the nutrient characteristics of the Pear River sediment, the TOC and $\mathrm{NO}_{2}^{-}$had the most significant impact on the nirS-encoding bacterial community structure and spatial distributions (Fig. 2b). Organic carbon was the primary electron donor for the respiratory denitrifying bacteria (Burgin and Hamilton, 2007). Although the abundance of nir genes was not restricted by the TOC concentrations, the diversity of nirS genes was closely related to TOC in the sediment (Figs. 2a, b). As a direct electron acceptor of denitrification, $\mathrm{NO}_{2}^{-}$concentrations had great impact on the quantity of nirS and nirK. However, none of the denitrifier clusters was limited by $\mathrm{NO}_{2}^{-}$concentrations directly (Figs. 2a, b), suggesting that distributions of denitrifying bacteria in the sediment were determined by combined effects of $\mathrm{NO}_{2}^{-}$and other depth-dependent factors. Environmental factors that restrict the nos $Z$ distribution also deserve to be studied because $n o s Z$ is the key functional gene for the complete denitrification. The CCA analysis showed that abundance of nos $Z$ was higher at the least nutrient condition in the sediment. This result was contrary to that of Laverman et al. (2010), who considered that higher numbers of nos $Z$ appeared in nutrientrich sediment and clean river might reduce the efficiency of $\mathrm{N}_{2}$ production. Our result implied that the distribution of nos $Z$ was not limited by concentrations of organic carbon or nitrogen but by the ratios of them. The uncertain conclusions about NO reduction and nos $Z$ need for further studies.

\section{Conclusions}

A direct relationship was established between the depthdependent environmental characteristics and the distributions of various denitrifying genes as well as the structure of nirSencoding denitrifier community in the Pearl River sediment. It was found that the diversity of the denitrifier communities was high in the sediment because the river sediment was affected by both domestic sewage inputs and irregular tides. The sediment depth and nutrient conditions were the major factors to control the distributions and diversities of denitrifying genes. Denitrification stratification in the sediment could be classified based on the vertical distribution of denitrifying genes and DIN. Many novel nirS-encoding denitrifiers were found in this typical sediment environment. The physiology and ecological roles of these novel denitrifiers in the nitrogen transformation and contaminants degradation in the environment should be of great interests in future studies.

Acknowledgements. This work was partly supported by grants from the Chinese National Natural Science Foundation (Nos. 51039007 and 51179212) and the Fundamental Research Funds for the Central Universities.

Edited by: K. Küsel

\section{References}

Akaike, H.: Information theory as an extension of the maximum likelihood principle, edited by: Petrov, B. N. and Csaki, F., Second international symposium of information theory, Akademiai Kiado, Budapest, Hungary, 1973.

Beller, H. R., Chain, P. S. G., Letain, T. E., Chakicherla, A., Richardson, P. M., Coleman, M. A., Wood, A. P., and Kelly, D. P.: The Genome sequence of the obligately chemolithoautotrophic, facultatively anaerobic bacterium Thiobacillus denitrificans, J. Bacteriol., 188, 1473-1488, 2006.

Braker, G., Fesefeldt, A., and Witzel, K. P.: Development of PCR primer systems for amplification of nitrite reductase genes (nirK 
and nirS) to detect denitrifying bacteria in environmental samples, Appl. Environ. Microb., 64, 3769-3775, 1998.

Bulow, S. E., Francis, C. A., Jackson, G. A., and Ward, B. B.: Sediment denitrifier community composition and nirS gene expression investigated with functional gene microarrays, Environ. Microb., 10, 3057-3069, 2008.

Burgin, A. J. and Hamilton, S. K.: Have we overemphasized the role of denitrification in aquatic ecosystems? A review of nitrate removal pathways, Front. Ecol. Environ., 5, 89-96, 2007.

Bustin, S. A., Benes, V., Garson, J. A., Hellemans, J., Huggett, J., Kuista, M., Mueller, R., and Nolan, T.: The MIQE Guidelines: Minimum Information for Publication of Quantitative Real-Time PCR Experiments, Clin. Chem., 55, 611-622, 2009.

Canfield, D. E., Glazer, A. N., and Falkowski, P. G.: The evolution and future of earth's nitrogen cycle, Science, 330, 192, 2010.

Casamayor, E. O., Pedrós-Alió, C., Muyzer, G., and Amann, R.: Microheterogeneity in $16 \mathrm{~S}$ rDNA-defined bacterial populations from a stratified planktonic environment is related to temporal changes and to ecological adaptations, Appl. Environ Microbiol., 68, 1706-1714, 2002.

Castro-Gonázlez, M., Braker, G., Farias, L., and Ulloa, O.: Communities of nirS-type denitrifiers in the water column of oxygen minimum zone in the eastern South Pacific, Environ. Microb., 7, 1298-1306, 2005.

Chakraborty, R., O'Connor, S. M., Chan, E., and Coates, J. D.: Anaerobic degradation of benzene, toluene, ethylbenzene, and xylene compounds by Dechloromonas Strain RCB, Appl. Environ. Microb., 71, 8649-8655, 2005.

Chon, K., Chang, J., Lee, E., Lee, J., Ryu, J., and Cho, J.: Abundance of denitrifying genes coding for nitrate (narG), nitrite (nirS), and nitrous oxide (nosZ) reductases in estuarine versus wastewater effluent-fed constructed wetlands, Ecol. Eng., 37, 64-69, 2011.

Dalsgaard, T., Thamdrup, B, and Canfield, D. E.: Anaerobic ammonium oxidation (anammox) in the marine environment, Res. Microbiol., 156, 457-464, 2005.

Dang, H., Zhang, X., Sun, J., and Li, T.: Diversity and spatial distribution of sediment ammonia-oxidizing crenarchaeota in response to estuarine and environmental gradients in the Changjiang Estuary and East China Sea, Microbiol., 154, 20842095, 2008.

Dang, H., Wang, C., Li, J., Li, T., Tian, F., Jin, W., Ding, Y., and Zhang, Z.: Diversity and distribution of sediment nirS-encoding bacterial assemblages in response to environmental gradients in eutrophied Jiaozhou Bay, China, Microb. Ecol., 58, 161-169, 2009.

Deiglmayr, K., Philippot, L., Hartwig, U. A., and Kandeler, E.: Structure and activity of the nitrate-reducing community in the rhizosphere of Lolium perenne and Trifolium repens under longterm elevated atmospheric $p \mathrm{CO}_{2}$. FEMS Microbiol. Ecol., 49, 445-454, 2004.

Desnues, C., Michotey, V., Wieland, A., Zhizang, C., Fourcans, A., Duran, R., and Bonin, P.: Seasonal and diel distributions of denitrifying and bacterial communities in a hypersaline microbial mat (Camargue, France), Water Res., 41, 3407-3419, 2007.

Dodla, S. K., Wang, J. J., Delaune, R. D., and Cook, R. L.: Denitrification potential and its relation to organic carbon quality in three coastal wetland soils, Sci. Tot. Environ., 407, 471-480, 2008.

Dong, L. F., Smith, C. J., Papaspyrou, S., Stott, A., Osborn, A. M., and Nedwell, D. B.: Changes in benthic denitrification, nitrate ammonification, and anammox process rates and nitrate and nitrite reductase gene abundances along an estuarine nutrient gradient (the Clone Estuary, United Kingdom), Appl. Environ. Microb., 75, 3171-3179, 2009.

Falk, S., Hannig, M., Gliesche, C., Wardenga, R., Köster, M., Jürgens, K., and Braker, G.: nirS-containing denitrifier communities in the water column and sediment of the Baltic Sea, Biogeosciences, 4, 255-268, doi:10.5194/bg-4-255-2007, 2007.

Fan, L. F., Shieh, W. Y., Wu, W. F., and Chen, C. P.: Distribution of nitrogenous nutrients and denitrifiers strains in estuarine sediment profiles of the Tanshui River, northern Taiwan, Estuar. Coast. Shelf. S., 69, 543-553, 2006.

Fukushima, T., Uda, N., Okamoto, M., Satoh, H., and Mino, T.: Development of the quantitative PCR method for Candidatus "Accumulibacter phosphatis" and its application to activated sludge, J. Water Environ. Technol., 5, 37-43, 2007.

Glockner, A., Jüngst, A., and Zumft, W.: Copper containing nitrite reductases from Pseudomonas aureofaciens is functional in mutationally cytochrome cd1-free background (NirS ${ }^{-}$) of Pseudomonas stutzeri, Arch. Microbiol., 160, 2136-2141, 1993.

Graham, D., Trippett, C., Dodds, W., O’Brien, J., Banner, E., Head, I., Smith, M., Yang, R., and Knapp, C.: Correlations between in situ denitrification activity and nir-gene abundances in pristine and impacted prairie streams, Environ. Pollut., 158, 3225-3229, 2010.

Huang, S., Chen, C., Wu, Y., Wu, Q., and Zhang, R.: Characterization of depth-related bacterial communities and their relationships with the environmental factors in the river sediments, World J. Microbiol. Biotechnol., 27, 2655-2664, 2011.

Huelsenbeck, J. P., Ronquist, F. R., Nielsen, R., and Bollback, J. P.: Bayesian inference of phylogeny and its impact on evolutionary biology, Science, 294, 2310-2314, 2001.

Jung, S., Lee, M., Oh, T., and Yoon, J.: Herbaspirillum rhizosphaerae sp. nov., isolated from rhizosphere soil of Allium victorialis var. platyphyllum, Int. J. Syst. Evol. Micr., 57, 2284 2288, 2007.

Knapp, C., Dodds, W., Wilson, K., O’Brien, J., and Graham, D.: Spatial heterogeneity of denitrification genes in a highly homogenous urban stream, Environ. Sci. Technol., 43, 4273-4279, 2009.

Kuypers, M. M. M., Sliekers, A. O., Lavik, G., Schmid, M., Jørgensen, B. B., Kuenen, J. G., Sinninghe Damsté, J. S., Strous, M., and Jetten, M. S.: Anaerobic ammonium oxidation by anammox bacteria in the Black Sea, Nature, 422, 608-611, 2003.

Laverman, A. M., Garnier, J. A., Mounier, E. M., and RooseAmsaleg, C. L.: Nitrous oxide production kinetics during nitrate reduction in river sediments, Water Res., 44, 1753-1764, 2010.

Liu, X., Tiquia, S. M., Holguin, G., Wu, L., Nold, S.C., Devol, A. H., Luo, K., Palumbo, A. V., Tiedje, J. M., and Zhou, J.: Molecular diversity of denitrifying genes in continental margin sediments within the oxygen-deficient zone off the pacific coast of Mexico, Appl. Environ. Microbiol., 69, 3549-3560, 2003.

Magalhães, C., Bano, N., Wiebe, W. J., Bordalo, A. A., and Hollibaugh, J. T.: Dynamics of nitrous oxide reductase genes (nosZ) in intertidal rocky biofilms and sediments of the Douro River Estuary (Portugal), and their relation to N-biogeochemistry, Microb. Ecol., 55, 259-269, 2008.

Martins, M., Faleiro, M. L., Chaves, S., Tenreiro, R., Santos, E., 
and Costa, M.: Anaerobic bio-removal of uranium (VI) and chromium (VI): comparison of microbial community structure, J. Hazard Mater., 176, 1062-1072, 2010.

Matsunaga, T., Okamura, Y., Fukuda, Y., Wahyudi, A. T., Murase, Y., and Takeyama, H.: Complete genome sequence of the facultative anaerobic magnetotactic bacterium Magnetospirillum sp. strain AMB-1, DNA Res., 12, 157-166, 2005.

Meyer, R. L., Allen, D. E., and Schmidt, S.: Nitrification and denitrification as sources of sediment nitrous oxide production: A microsensor approach, Mar. Chem., 110, 68-76, 2008.

Mullins, T. D., Britschgi, T. B., Krest, R. L., and Giovannoni, S. J.: Genetic comparisons reveal the same unknown bacterial lineages in Atlantic and Pacific bacterioplankton communities, Limnol. Oceanogr., 40, 148-158, 1995.

Nogales, B., Timmis, K. N., Nedwell, D. B., and Osborn, A. M.: Detection and diversity of expressed denitrification genes in estuarine sediments after reverse transcription-PCR amplification from mRNA, Appl. Environ. Microb., 68, 5017-5025, 2002.

Nylander, J. A. A.: MrModeltest v2. Program distributed by the author. Evolutionary Biology Centre, Uppsala University, 2004.

Oakley, B. B., Francis, C. A., Roberts, K. J., Fuchsman, C. A., Srinivasan, S., and Staley, J. T.: Analysis of nitrite reductase (nirK and nirS) genes and cultivation reveal depauperate community of denitrifying bacteria in the Black Sea suboxic zone, Environ. Microbiol., 9, 118-130, 2007.

Osaka, T., Yoshie, S., Tsuneda, S., Hirata, A., Iwami, N., and Inamori, Y.: Identification of acetate- or methanol-assimilating bacteria under nitrate-reducing conditions by stable-isotope probing, Microb. Ecol., 52, 253-266, 2006.

Priemé, A., Braker, G., and Tiedje, J. M.: Diversity of nitrite reductase (nirK and nirS) gene fragments in forested upland and wetland soils, Appl. Environ. Microb., 68, 1893-1900, 2002.

Rambaut, A. and Drummond, A. J.: Tracer v1.5, Available at http: //beast.bio.ed.ac.uk/Tracer, last access: 5 March 2010, 2009.

Reyna, L., Wunderlin, D. A., and Genti-Raimondi, S.: Identification and quantification of a novel nitrate-reducing community in sediments of Suquía River basin along a nitrate gradient, Environ. Pollut., 158, 1608-1614, 2010.

Richardson, W. B., Strauss, E. A., Bartsch, L. A., Monroe, E. M., Cavanaugh, J. C., Vingum, L., and Soballe, D. M.: Denitrification in the Upper Mississippi River: rates, controls, and contribution to nitrate flux, Can. J. Fish. Aquat. Sci., 61, 1102-1112, 2004.

Ronquist, F. R. and Huelsenbeck, J. P.: MrBayes 3: Bayesian phylogenetic inference under mixed models, Bioinformatics, 19, 1572-1574, 2003.

Ruiz-Rueda, O., Trias, R., Garcia-Gil, L. J., and Bañeras, L.: Diversity of the nitrite reductase gene nirS in the sediment of a freewater surface constructed wetland, Int. Microbiol., 10, 253-260, 2007.

Ryan, J., Estefan, G. and Rashid, A.: Soil and plant analysis laboratory manual. Jointly published by International Center for Agricultural Research in the Dry Areas (ICARDA) and the National Agricultural Research Center (NARC), USA, 2001.
Rysgaard, S., Risgaard-Petersen, N., Nielsen, L. P., and Revsbech, N. P.: Nitrification and denitrificaiton in lake and estuarine sediments measured by the ${ }^{15} \mathrm{~N}$ dilution technique and isotope pairing, Appl. Environ. Microb., 59, 2093-2098, 1993.

Scala, D. J. and Kerkhof, L. J., Nitrous oxide reductase (nosZ) genespecific PCR primers for detection of denitrifiers and three nos $Z$ genes from marine sediments, FEMS Microbiol. Lett., 162, 6168, 1998.

Schloss, P. D. and Handelsman, J.: Introducing DOTUR, a computer program for defining operational taxonomic units and estimating species richness, Appl. Environ. Microb., 71, 1501-1506, 2005.

Schwartz, E., Henne, A., Cramm, R., Eitinger, T., Friedrich, B., and Gottschalk, G.: Complete nucleotide sequence of pHG1: a Ralstonia eutropha H16 megaplasmid enconding key enzymes of H2-based lithoautotrophy and anaerobiosis, J. Mol. Biol., 332, 369-383, 2003.

Scott, J. T., McCarthy, M. J., Gardner, W. S., and Doyle, R. D.: Denitrification, dissimilatory nitrate reduction to ammonium, and nitrogen fixation along a nitrate concentration gradient in a created freshwater wetland, Biogeochemistry, 87, 99-111, 2008.

Smith, C. J., Nedwell, D. B., Dong, L. F., and Osborn, A. M.: Diversity and abundance of nitrate reductase genes (narG and napA), nitrite reductase genes (nirS and $n r f A$ ), and their transcripts in estuarine sediments, Appl. Environ. Microb., 73, 3612-3622, 2007.

Spain, A. M., Peacock, A. D., Istok, J. D., Elshahed M. S., Najar, F. Z., Roe, B. A., White, D. C., and Krumholz, L. R.: Identification and isolation of a Castellaniella species important during biostimulation of an acidic nitrate- and uranium-contaminated aquifer, Appl. Environ. Microb., 73, 4892-904, 2007.

Tamang, D. G., Rabus, R., Barabote, R. D., and Saier Jr., M. H.: Comprehensive analyses of transport proteins encoded within the genome of "Aromatoleum aromaticum" strain EbN1, J. Membrane Biol., 229, 53-90, 2009.

Throbäck, I. N., Enwall, K., Jarvis, Å., and Hallin, S.: Reassessing PCR primers targeting nirS, nirK and nos $Z$ genes for community surveys of denitrifying bacteria with DGGE, FEMS Microbiol. Ecol., 49, 401-417, 2004.

Tiquia, S. M., Masson, S. A., and Devol, A.: Vertical distribution of nitrite reductase genes (nirS) in continental margin sediments of the Gulf of Mexico, FEMS Microbiol. Ecol., 58, 464-475, 2006.

Tsuneda, S., Miyauchi, R., Ohno, T., and Hirata, A.: Characterization of denitrifying polyphosphate-accumulating organisms in activated sludge based on nitrite reductase gene, J. Biosci. Bioneng., 99, 403-407, 2005.

Wongwilaiwalin, S., Rattanachomsri, U., Laothanachareon, T., Eurwilaichitr, L., Igarashi, Y., and Champreda, V.: Analysis of a thermophilic lignocellulose degrading microbial consortium and multi-species lignocellulolytic enzyme system, Enzyme Microb. Tech., 47, 283-290, 2010.

Yan, T., Fields, M., Wu, L., Zu, Y., Tiedje, J., and Zhou, J.: Molecular diversity and characterization of nitrate- and uraniumcontaminated groundwater, Environ. Microbiol., 5, 13-24, 2003.

Zumft, W.: Cell biology and molecular basis of denitrification, Microbiol. Mol. Biol. Rev., 61, 533-616, 1997. 